\title{
PENGARUH KONSELING KELOMPOK BEHAVIORAL TEKNIK LATIHAN ASERTIF DALAM MEMINIMALISASI PERILAKU MEMBOLOS PADA SISWA SMK MUHAMMADIYAH 6 ROGOJAMPI TAHUN AJARAN 2017/2018
}

\author{
Siti Nurhalimah ${ }^{1}$, Siti Napisah ${ }^{2}$ \\ Fakultas Keguruan dan Ilmu Pendidikan, Universitas PGRI Banyuwangi \\ Email : halimcan7550@gmail.com ${ }^{1}$ \\ Email : napisah_s@yahoo.com²
}

\begin{abstract}
Abstrak
Perilaku membolos merupakan perilaku menyimpang dari aturan sekolah yang sangat merugikan dirinya sendiri karena dapat berengaruh terhadap akademik. Perilaku membolos dapat bersumber dari diri siswa sendiri atau faktor lingkungan. Tujuan dari penelitian ini adalah untuk menguji pengaruh konseling kelompok dengan pendekatan behavioral teknik latihan asertif untuk meminimaisasi perilaku membolos siswa SMK Muhamadiyah 6 Rogojampi kelas X TKR. Jumlah sampel 20 orang siswa. Metode penelitian ini menggunakan rancangan Non equivalent Pretest-Posttest Control Group Design.
\end{abstract}

Kata Kunci : Behavioral, Teknik Latihan Asertif, perilaku membolos

\begin{abstract}
Abstrack
Skipping behavior is a deviant behavior of school rules that is very detrimental to itself because can affect the academic. The truancy behavior can come from students themselves or environmental factors. The purpose of this study is to examine the effect of group counseling with behavioral approach of assertive training techniques to minimize the behavior of ditching students of SMK Muhamadiyah 6 Rogojampi class X TKR. The sample size is 20 students. This research method uses non equivalent Pretest-Posttest Control Group Design design.
\end{abstract}

Keyword : Behavioral, assertive training techniques, skipping behavior

\section{PENDAhUluan}

Pendidikan adalah usaha yang dilakukan secara terencana untuk membantu individu mengembangkan potensi-potensi dirinya sehingga memiliki kekuatan spiritual keagamaan, pengendalian diri, kepribadian, kecerdasan, akhlak mulia, serta keterampilan

yang diperlukan dalam kehidupan bermasyarakat, berbangsa dan bernegara (UU No. 20 Tahun 2003). Sesuai dengan tujuan pendidikan nasional, pengembangan 
FKIP Universitas PGRI Banyuwangi Seminar Nasional

Pendidikan Budaya dan Sejarah: "Dibalik Revitalisasi Budaya"

ISBN: 978-602-72362-7-1

potensi-potensi tersebut dimaksudkan untuk membentuk individu menjadi manusia yang beriman dan bertakwa kepada Tuhan Yang Maha Esa, berakhlak mulia, sehat, berilmu, cakap, kreatif, mandiri, dan menjadi warga negara yang demokratis serta bertanggung jawab.

Dalam dunia pendidikan siswa dihadapkan dengan berbagai masalah yang dapat mengganggu proses pendidikan yang dijalaninya, tidak hanya masalah dalam memahami materi pelajaran tetapi siswa juga mengalami masalah dalam kehidupan pribadi dan sosialnya seperti, siswa memiliki hubungan tidak baik dengan teeman sekolahnya sehingga menyebabkan siswa tersebut tidak masuk kelas. Masalahmasalah tersebut tentunya perlu segera diselesaikan agar siswa dapat berkonsentrasi dalam kegiatan belajarnya dan mengembangkan potensi-potensi yang dimilikinya secara optimal.

Perilaku membolos merupakan salah satu perilaku yang memberikan dampak negatif untuk perkembangan optimal siswa. Perilaku membolos ialah perilaku tidak masuk sekolah, meninggalkan sekolah, ataupun jam pelajaran sebelum selesai yang dilakukan tanpa mendapatkan izin dari sekolah yang dapat disebabkan oleh faktor

DOI: $10.31227 /$ osf.io pribadi, keluarga, teman atau lingkungan sekolah.

Perilaku membolos sebenarnya bukan merupakan hal yang baru lagi bagi sebagian besar siswa. Tindakan membolos merupakan salah satu tindakan siswa untuk melampiaskan kejenuhan mereka akan pendidikan. Membolos memang telah menjadi fenomena yang jelas-jelas mencoreng lembaga pendidikan dan siswa itu sendiri. Tindakan membolos ini tidak hanya di kota-kota besar saja siswa yang terlihat sering membolos, bahkan di daerahdaerah perilaku membolos sudah menjadi kegemaran atau tren.

Banyak siswa yang sering membolos semua itu disebabkan oleh faktor-faktor internal dan eksternal dari siswa itu sendiri. Faktor eksternal yang kadang kala menjadikan alasan. membolos adalah mata pelajaran yang tidak diminati dan tidak suka dengan guru mata pelajaran. Dan faktor internal yakni siswa menganggap masa remaja adalah masa pencarian jati diri yang penuh dengan jiwa yang mementingkan kebebasan dalam berfikir dan ber kreativitas. Mereka yang tidak dapat beradaptasi dengan situasi seperti itu mereka akan mencari penyelesaian lain dengan cara membolos. Walaupun begitu membolos sebenarnya 
FKIP Universitas PGRI Banyuwangi Seminar Nasional

Pendidikan Budaya dan Sejarah: "Dibalik Revitalisasi Budaya"

ISBN: 978-602-72362-7-1

bukan jawaban yang utama untuk melampiaskan keadaan yang seperti itu. Dan kegiatan membolos juga hal yang dapat melatar belakangi timbul masalah masalah lain. Terbukti siswa yang suka membolos seringkali terlibat dengan hal-hal yang cenderung merugikan diri sendiri dan orang lain seperti merokok, tawuran, dan pergaulan bebas. Unsur-unsur yang ada di sekolah bisa saja menjadi alasan siswa bisa membolos. Bila ini terus-terusan dibiarkan bukan saja siswa itu sendiri tetapi juga sekolah dan guru yang menjadi orang tua di sekolah yang menangungnya.

Membolos itu merupakan salah satu faktor penyebab lingkungan atau iklim sekolah yang tidak sehat. Dan siswa merupakan aktor utama dalam peristiwa tersebut. Kalau ditanya mengapa terjadi siswa membolos? Tentu jawabannya akan dikaitkan dengan tokoh pemainnya, yaitu para siswa itu sendiri, mengapa mereka bisa berbuat demikian.

Membolos merupakan salah satu bentuk perilaku siswa yang menyimpang dari aturan sekolah. Membolos disebut menyimpang karena merupakan perilaku yang melanggar aturan sekolah. Sedangkan dampak buruk bagi sekolah, siswa yang suka membolos sering mencontoh gaya penampilan teman sebaya dari sekolah lain yang tidak sesuai dengan aturan yang ada di sekolahnya sehingga menghambat kedisiplinan yang diterapkan dan siswa yang membolos dapat menghambat pencapaian tujuan pembelajaran di kelas.

Berdasarkan hasil Observasi dari keterangan guru BK Ibu Sunariyah, S.Pd., diketahui pada tahun ajaran 2017/2018 dari 16 kelas $\mathrm{X}$, siswanya mengalami peningkatan masalah membolos siswa yang membolos jika dihitung bisa mencapai 14 siswa. Dilihat dari seluruh kels $\mathrm{X}$ yang ter bagi menjadi kelas (TKR, TKJ, ACP, RPL, dan TSM) di SMK Muhammadiyah 6 Rogojampi yang memiliki persentase rendah yaitu kelas X. Penyebab siswa membolos di SMK Muhammadiyah 6 Rogojampi ialah kurang tertarik dengan mata pelajaran tertentu yang dimaksud disini siswa kurang menyukai mata pelajaran yang dianggap siswa tersebut sulit atau factor gurunya yang kurag disukai, tidak mengerjakan tugas, karena terpengaruh oleh ajakan teman yang mengajak untuk nongkrong, makan-makan dan merokok. Serta ada siswa yang menyempelehkan guru misalkan pada saat guru tersebut guru yang dianggap santai saat megajar siswa tersebut membolos, 
FKIP Universitas PGRI Banyuwangi Seminar Nasional

Pendidikan Budaya dan Sejarah: "Dibalik Revitalisasi Budaya"

ISBN: 978-602-72362-7-1

sedangkan pada saat guru yang killer mereka masuk kelas, tidak masuk mulai jam pertama hingga terakhir dan terpengaruh ajakan pacar.

Oleh karena itu dibutuhkan bantuan konselor atau guru pembimbing sekolah untuk mengatasi tingkah laku membolos tersebut. Usaha-usaha yang telah dilakukan pihak sekolah sendiri sudah melakukan

a. Bimbingan Kelompok menurut Dewa ketut sukardi (2008:64) bimbingan kelompok yaitu layanan bimbingan yang memungkinkan sejumblah peserta didik secara brsama-sama memperoleh berbagai bahan dari narasumber tertentu (terutama dari pembimbing/ konselor) yang berguna untuk menunjang kehidupan sehari-hari baik individu maupun pelajar, anggota keluarga dan masyarakat serta untuk pertimbangan dalam pengambilan keputusan seharusnya bimbingan kelompok ini bisa untuk mengurangi perilaku membolos.

b. Bimbingan Klasikal meurut Santoso (2011:39) Bimbingan Kelas (Klasikal) adalah program yang melakukan yang dirancang menuntut konseor untuk melakukan kontang langsung dengan peserta didik di kelas. Secara terjadwal, konselor memberikan pelayanan bimbingan kepada peserta didik. Kegiatan bimbingan kelas ini bisa berupa diskusi kelas atau brain storming (curah pendapat).

Seharusnya kedua bimbingan tersebut bisa efektif untuk mengurangi perilaku membolos pada siswa, tetapi kenyataanya tidak efektif untuk meminimalisasi peilaku membolos siswa. Karena kedua layanan tersebut tidak efektif disini penelititi akan menggunakaan konseing kelompok behavioral teknik latihan asertif.

konseling kelompok behavioral dengan teknik latihan asertif di berikan kepada siswa yang membolos, digunakan untuk melihat siswa yang mengalami kesulitan untuk menyatakan diri bahwa tindakanya adalah layak atau benar. Latihan ini terutama berguna diantaranya untuk membantu individu yang tidak mampu mengungkapkan perasaan tersinggung. Kesulitan menyatakan tidak, mengungkapkan afeksi dan positif lainya. Diskusi-diskusi kelompok juga dapat diterapkan dalam latihan asertif. Dengan memperhatikan penyebab perilaku membolos, maka teknik latihan asertif 
FKIP Universitas PGRI Banyuwangi Seminar Nasional

Pendidikan Budaya dan Sejarah: "Dibalik Revitalisasi Budaya"

ISBN: 978-602-72362-7-1

sesuai untuk menyelesaikan masalah siswasiswa yang membolos.

\section{KAJIAN LITERATUR DAN PENGEMBANGAN HIPOTESIS}

a. Pengertian Perilaku Membolos

Menurut Mustaqim dan Wahib (Khanisa, 2012:28) perilaku membolos adalah suatu bentuk perbuatan yang dilakukan siswa dengan sengaja meninggalkan pelajaran atau meninggalkan sekolah tanpa izin terlebih dahulu atau tanpa keterangan. Tidak masuk sekolah dengan alasan yang tidak tepat dan tanpa alasan yang jelas.

Membolos dapat diartikan sebagai perilaku peserta didik yang tidak masuk sekolah dengan alasan yang tidak tepat. Atau bisa juga dikatakan ketidak hadiran tanpa alasan yang jelas serta alasan yang logis. Membolos merupakan salah satu bentuk dari kenakalan peserta didik, yang jika tidak segera diselesaikan atau dicari solusinnya dapat menimbulkan dampak yang lebih parah. Oleh karena itu, penanganan terhadap peserta didik yang suka membolos menjadi perhatian yang sangat serius oleh semua pemimbing serta guru mata pelajaran dan peran orang tua peserta didik itu sendiri.
Adapun cirri-ciri siswa yang membolos adalah Menurut Mustaqim dan Wahib (Khanisa, 2012:33) ciri-ciri siswa yang suka membolos yaitu : Sering tidak masuk sekolah, tidak memperhatikan guru dalam menjelaskan materi, Mempunyai perilaku yang tidak baik, berlebih-lebihan atau antara lain dalam berbicara maupun dalam cara berpakaian, Meninggalkan sekolah, sebelum jam pelajaran selesai, Tidak bertanggung jawab pada studinya, Kurang berminat pada mata pelajarannya, Datang sering terlambat, Tidak mengikuti pelajaran, Tidak mengerjakan tugas, Tidak menghargai guru di kelas.

\section{b. Konseling Kelompok Pendekatan \\ Behavioral Teknik Latihan Asertif \\ Tahapan tahapan koneling kelompok} pada umumnya ada empat tahap perkembangan dalam konseling kelompok, yang meliputi: (1) tahap pembentukan/tahap awal (2) tahap peralihan (3) tahap pelaksanaan kegiatan, dan (4) tahap pengakhiran. Masing-masing tahap tersebut memiliki karakteristik tertentu. (Prayitno, 2004)

Latihan asertif adalah suatu kemampuan untuk mengkomunikasikan apa yang diinginkan, dirasakan dan dipikirkan pada orang lain namun tetap 
FKIP Universitas PGRI Banyuwangi Seminar Nasional

Pendidikan Budaya dan Sejarah: "Dibalik Revitalisasi Budaya"

ISBN: 978-602-72362-7-1

menjaga dan menghargai hak-hak serta perasaan orang lain. Latihan asertif ini diberikan pada individu yang mengalami kecemasan, tidak mampu mempertahankan hak-haknya, terlalu lemah, membiarkan orang lain melecehkan dirinya, tidak mampu mengekspresikan amarahnya dengan benar dan cepat tersinggung.

Berdasarkan landasan teori diatas, maka hipotesis yang diajukan dalam penelitian ini adalah, (1) Konseling kelompok Behavioral teknik latihan asertif berpengaruh dalam meminimalisasi perilaku membolos siswa kelas XI SMK PGRI Rogojampi (2) Terdapat perbedaan penurunan perilaku membolos siswa antara kelompok eksperimen dan kelompok kontrol.

\section{METODELOGI PENELITIAN}

\section{a. Populasi Penelitian}

Menurut sugiyono pengertian populasi adalah wilayah gineralisasi yang terdiri atas: obyek/subyek yang mempunyai kualitas dan karakteristik tertentu yang ditepatkan oleh peneliti untuk dipelajari dan kemudian ditarik kesimpulanya (sugiyono, 2011:80). Populasi yang digunakan dalam penelitian ini adalah siswa kelas $\mathrm{X}$ TKR sejumlah
266 siswa di SMK Muhammadiyah 6 Rogojampi Tahun Ajaran 2017/2018.

\section{b. Sampel Penelitian}

Pengambilan Sampel penelitian ini adalah Siswa SMK kelas X TKR yang terindikasi rendahnya kontrol diri, dengan menggunakan konseling kelompok behavioral teknik latihan aserif dapat meminimalisasi perilaku membolos. Teknik pengambilan sampel ini menggunakan Purposive Sampling.

\section{c. Metode Pengumpulan Data}

Metode pengumpulan ini menggunakan metode observasi, wawancara, dan kuisoner.Penyebaran kuisioner perilaku membolos di berikan kepada 266 siswa kelas X TKR SMK Muhammadiyah 6 Rogojampi. Sebelum kuisioner di sebarkan dilakukan uji validitas isi yaitu validitas yang ditentukan oleh derajat reprentativitas butir-butir instrument yang disusun telah mewakili keseluruhan materi yang hendak diukur tersebut. Untuk mengetahui validitas isi kuesioner perilaku membolos yang digunakan. maka perlu dilakukan penilaian ahli (expert judgement) oleh dua orang ahli.Setelah analisis validitas isi tersebut, dilanjutkan dengan melakukan uji validitas butir melalui analisis butir. Suatu angket 
FKIP Universitas PGRI Banyuwangi Seminar Nasional

Pendidikan Budaya dan Sejarah: "Dibalik Revitalisasi Budaya"

ISBN: 978-602-72362-7-1

(kuesioner) dikatakan valid jika pernyataan/pernyataan pada suatu kuesioner mampu untuk mengungkapkan sesuatu yang akan di ukur oleh kuesioner tersebut (Nurkancana, 1990: 232). Setelah validitas isi dan validitas butir dilakukan, maka selanjutnya dilakukan uji reabilitas (keandalan). Suatu kuisioner dikatakan reliabel "apabila tes tersebut menunjukkan hasil-hasil yang mantap". (Nurkanca, 1993:144).

Setelah mendapat data kusioner perilaku membolos akan dilakukan analisis data secara deskriptif. Data instrumen perilaku membolos dianalisis secara deskriptif dan dinyatakan dengan jenjang kualifikasi. Jenjang kualifikasi dikategorikan berdasarkan skor rata-rata $(\bar{X})$, mean ideal (Mi), dan standart deviasi ideal $\left(\mathrm{SD}_{\mathrm{i}}\right)$. Uji prasyarat analisis yaitu (1) uji normalitas adalah sebaran data dilakukan untuk meyakinkan bahwa data yang dihasilkan dalam penelitian benarbenar berdistribusi normal, sehingga uji hipotesis dapat dilakukan. (2) Uji homogenitas digunakan untuk mengetahui apakah kelompok-kelompok sampel berasal dari populasi yang sama. Kesamaan asal sampel ini dibuktikan dengan adanya kesamaan varians

DOI: $10.31227 /$ osf.io kelompok-kelompok yang membentuk sampel tersebut. (3) Uji Hipotesis Sebagai langkah lebih lanjut dalam penelitian ini, dilakukan suatu produser analisis terhadap data-data yang diperoleh peneliti. Tujuan dari analisis data ini adalah mengungkapkan apa yang ingin diketahui dari peneliti. Dalam menganalisis data yang diperoleh selama melakukan penelitian, penulis menggunakan dua analisis statistik, antara lain (1) analisis statistik correlated data/paired sampel ttest dan (2) analisis statistik uncorrelated data/independent sampel t-test.

Dasar pengambilan keputusannya adalah : (a) Jika t hitung > t tabel, maka $\mathrm{H}_{\mathrm{o}}$ ditolak, (b) Jika t hitung < t tabel, maka $\mathrm{H}_{\mathrm{o}}$ diterima. Berdasarkan nilai probabilitinya : (1) Jika probabilitas > 0,05 maka $\mathrm{H}_{\mathrm{o}}$ diterima, (2) Jika probabilitas < 0,05 maka $\mathrm{H}_{\mathrm{o}}$ ditolak. Analisis statistik correlated data/paired sampel t-test dimaksudkan untuk mengetahui efektivitas atau pengaruh dari variabel bebas terhadap variabel terikat dilihat dari perbedaan pretest dengan posttest (Seniatai, Yulianto dan Setiadi, 2005:119). 
FKIP Universitas PGRI Banyuwangi Seminar Nasional

Pendidikan Budaya dan Sejarah: "Dibalik Revitalisasi Budaya"

ISBN: 978-602-72362-7-1

\section{RANCANGAN PENELITIAN}

Penelitian ini adalah penelitian kuantitatif dengan metode experimen. Rancangan penelitian kuantitatif ini yakni quasi experimental (ekseprimen semu). Desain penelitian ini menggunakan rancangan Non equivalent Pretest-Posttest Control Group Design. Rancangan control group design dipilih dengan pertimbangan bahwa dalam eksperimen semu, tidak memungkinkan untuk merandom subjek dalam kelompok populasi secara utuh. Selanjutnya pretest dan posttest berarti memberikan tes kepada subjek sebelum dan setelah perlakuan diberikan pada masing-masing kelompok. Rancangan ini dipilih karena penelitian ini merupakan penelitian terapeutik untuk mengetahui pengaruh perlakuan terhadap variabel terikat. Artinya rancangan pretest dan posttest digunakan untuk meminimalisasi perilaku membolos

\begin{tabular}{cccc}
$\mathrm{E}$ & $\mathrm{O}_{1}$ & $\mathrm{X}$ & $\mathrm{O}_{2}$ \\
\hline $\mathrm{K}$ & $\mathrm{O}_{1}$ & - & $\mathrm{O}_{2}$
\end{tabular}

(Sumber: Dantes, 2012:97)

Gambar 02. Desain Non Equivalent Pretest Posttest Control Group

E : kelompok eksperimen
K : kelompok control

$\mathrm{X}$ : konseling kelompok behavioral dengan teknik latihan asertif

- $\quad$ : konseling kelompok tanpa teknik khusus

O1 : pengamatan awal, berupa pre-test sebelum diberikan perlakuan.

O2 : Pengamatan akhir, yaitu pemberian post test setelah diberikan perlakuan.

\section{REFERENSI}

Adhiputra, A.A. Ngurah. 2014. Konseling Kelompok Perspektif Teori Dan Aplikasi. Yogyakarta: Media Akademi.

Anitiara. 2016. Pengaruh perilaku membolos di sekolah dengan menggunakan konseling kelompok pada siswa VIII SMP Negeri 2 kotabumi Tahun ajaran 2015/2016. Skripsi. [online], FKIP. Universitas lampung.

http://digilib.unila.ac.id/23887/7/SKRI PSI\%20TANPA\%20BAB\%20PEMB AHASAN.pdf. Di akses 12 April 2018

Dantes, Nyoman. 2012. Metode Penelitian. Yogyakarta: Penerbit Andi.

Dantes, Nyoman. 2014. Analisis dan Desain Eksperimen. Singaraja: Universitas Pendidikan Ganesha.

Diambil dari Buku peengembangan Profesi Bimbingan dan Konseling oleh Drs. Mochamad Nursalim, M. Si

Fatha Nur Aryati. 2015. Identifikasi Faktor penyebab perilaku membolos dan alternative pemecahanya pada siswa kelas IV di SD Negeri 1 purbalingga 
kodul. Artikel jurnal. [online]. FKIP Univesitas Negeri Yogyakarta. http:// journal.student.uny.ac.id/ojs/index.php /pgsd/article.vievFile/1179/1052/Artik el jurnal. Pdf. di akses 13 April 2018

Komalasari, Gantina dkk. 2011. Teori dan Teknik Konseling. Jakarta: PT. Indeks.

Koyan, I Wayan. 2012. Statistik Pendidikan (Teknik Analisis Data Kuantitatif). Singaraja: Undiksha Press.

Mehrens, W. A \& Lehmann, I. J. 1984. Measurement and evaluation in Education and Psychology, Third
Edition. New York: Holt, Rinehart and Winston.

Noor, Juliansyah. 2010. Metodelogi penelitian. Jakarta: Kencana Prenada Media Group.

Nurkancana, Wayan, 1993. Evaluasi Pendidikan. Surabaya: Usaha Nasional, Santoso, S. 2010. Statistik Multivariat. Jakarta: PT Elex Media Komputindo.

Nursalim, M.2015. pengembangan profesi bimbingan dan konseling. Jakarta: PT Gelora .Aksara Pratama. 